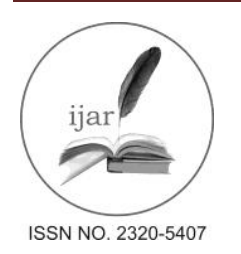

Journal homepage: http://www.journalijar.com
Journal DOI: 10.21474/IJAR01

RESEARCH ARTICLE

\title{
HEPATOPROTECTIVE EFFICACY OF THE METHANOL EXTRACT OF CYPRAEA ARABICA.
}

\author{
A. Bavanisaraswathy, R. D. Thilaga, A. Umamaheswari and S. Jeya Ruby. \\ P.G.and Research Department of Zoology, St.Mary's College (Autonomous) Tuticorin.
}

\section{Manuscript Info \\ Manuscript History: \\ Received: 22 February 2016 \\ Final Accepted: 18 March 2016 \\ Published Online: April 2016 \\ Key words: \\ Cypraeaarabica, Methanol, Hepatoprotective activity, \\ Paracetamol. \\ *Corresponding Author}

A.Bavanisaraswathy.

\section{Abstract}

The marine natural product has been an important source of the new pharmaceutical industry in the treatment of various diseases. Liver disease is a leading cause of death in many countries. The measures to control liver disease is still an endeavour to modern medicine. So the present study has been carried out to probe the impregnable, low-cost, active drug from marine gastropod Cypraeaarabica. The whole body extract of Cypraeaarabica was explored for its hepatoprotective effect on paracetamol induced liver damage in Wistar albino rats. Hepatoprotective activities were measured by determining the diagnostic marker enzymes such as SGPT, SGOT, ALP, bilirubin and values were estimated. The hepatic enzymes SGPT $(129.62 \pm 1.59)$ (Serum Glutamate Pyruvate Transaminase), SGOT $(143.65 \pm 1.01)$ (Serum Glutamate Oxaloacetate Transaminase), ALP $(88.93 \pm 0.49)$ (Alkaline Phosphatase) and bilirubin $(2.7 \pm 0.3)$ in serum were significantly $(\mathrm{P}<0.05)$ increased in paracetamol treated group when compared to control. The $\mathrm{F}_{3}$ fraction of Cypraeaarabica (200 and $400 \mathrm{mg} / \mathrm{kg}$ ) significantly decreased the level of hepatic enzymes and bilirubin. In the liver section of $F_{3}$ fraction of Cypraeaarabica the normal cellular shape was regained and restored. This result suggests that the Cypraeaarabica extract has a potential therapeutic value in the treatment of liver diseases.

Copy Right, IJAR, 2016.. All rights reserved.

\section{Introduction:-}

Pharmaceutical market is growing rapidly and continuously. But the demand for new drug discovery is encouraged. The marine environment is a huge source for yet to be discovered natural products. Molluscs in the ocean are a common sight and are virtually untapped resources of novel compounds. There are more than thousands of bioactive compounds discovered in molluscs (Blunt et al., 2006). Liver is a vital organ which plays a major role in metabolism and excretion of xenobiotics by regulating homeostasis and providing protection against foreign substances by detoxifying and eliminating them from the body (Meenakshi et al.,2013). Hepatitis is one of the major health problem which may sometimes even lead to death. Natural products may be the best source of remedies for the treatment of liver diseases. Thus identification of a potential therapeutic agent for the protection of liver from hepatotoxins will provide a useful way for the prevention of these liver related illness. Modern allopathic medicine has very little to offer for the treatment of liver disorders inspite of consistent effort for new drug discovery (Ravindra et al., 2015). Hence the present study has been carried out to elucidate the hepatoprotective activity of Cypraeaarabicaagainst paracetamol induced liver toxicity in male albino rats.

\section{Sample preparation (Thilaga 2005):-}

The gastropod Cypraeaarabica was collected from the coastal region of Gulf of Mannar in Thoothukudi by trawl nets used for capturing crab, brought to the laboratory, cleaned and washed with fresh sea water to remove all impurities. The shells were removed and then the tissues were dried in hot air oven at $56^{\circ} \mathrm{c}$ for 48 hrs. The dried tissue was immersed in $100 \%$ AR grade methanol for 10 days at room temperature. 
After filtration with Whatman No.1 filter paper, methanol extract was reduced by vacuum evaporation. The extract residue was resuspended in $20 \mathrm{ml}$ of $100 \%$ AR grade methanol. The methanol extracts were dried and solidified in deionized water. Different concentration of extracts were prepared and stored at $0^{\circ} \mathrm{c}$ for further studies.

\section{Fractionation:-}

Crude methanol extract was fractionated by silica gel column chromatography. The extract was fractionated with four solvent systems. Elutions with Hexane: chloroform $\left(F_{1}\right)$, chloroform $\left(F_{2}\right)$, Benzene; methanol $\left(F_{3}\right)$ and distilled water $\left(\mathrm{F}_{4}\right)$ in the order of their polarity afford four fractions $\mathrm{F}_{1}, \mathrm{~F}_{2}, \mathrm{~F}_{3}$, and $\mathrm{F}_{4}$. A known amount of extracts were taken and their organic solvents were removed by vacuum evaporation. Solids were dissolved in deionized water and concentration series of $1 \mathrm{mg} / \mathrm{ml}, 10 \mathrm{mg} / \mathrm{ml}$ and $100 \mathrm{mg} / \mathrm{ml}$ were prepared and used.

\section{Experimental animal:-}

Mature adult male Wistar albino rats weighing 180-200 gm were selected for the study. The selected animals were housed under standard environmental conditions (temperature of $24 \pm 2^{\circ} \mathrm{c}$ ) and were maintained by giving uniform pellet diet, water ad libitum with an alternating $12 \mathrm{hrs}$ of darkness and $12 \mathrm{hrs}$ of light schedule and humidity of (60-70\%). Prior approval of Institutional Animal Ethics Committee (IAEC) was obtained.

\section{Drugs and chemicals:-}

Silymarin and paracetamol were purachased from Micro Labs Ltd, Bangalore, India. Paracetamol induced liver damage in rats were studied in 5 groups (I-V) each comprising of 5 Wistar albino rats. Of the four fractions tested, the F3 fraction showed potent activity, hence this fraction was used for further study

\section{Induction of hepatotoxicity and hepatoprotectivity:-}

Group - I served as control and received orally normal saline $5 \mathrm{ml} / \mathrm{kg}$ body weight daily for 14 days intraperitonialy. Group - II rats were treated with Silymarin $(100 \mathrm{mg} / \mathrm{kg} / \mathrm{p} . \mathrm{o})$ and were considered as standard. Group - III rats were treated with paracetamol to induce hepatotoxicity by giving paracetamol ( $2 \mathrm{~g} / \mathrm{kg} \mathrm{p.o})$. Group - IV and Group - V animals were treated with $200 \mathrm{mg} / \mathrm{kg}, 400 \mathrm{mg} / \mathrm{kg}$ of F3 extract of Cypraeaarabica daily for 14 days through oral routes. On the $14^{\text {th }}$ day the paracetamol suspension was given orally a dose of $750 \mathrm{mg} / \mathrm{kg}$ to all rats except group - I. After $48 \mathrm{hrs}$ of administration of paracetamol dose the rats were sacrificed by cervical decapitation under Xyaline - Ketamine $(16+100 \mathrm{mg} / \mathrm{kg})$. Blood samples were collected via abdominal aorta puncture for biochemical parameters and the separated serum was used for the determination of diagnostic marker enzymes such as SGOT, SGPT, ALP, bilirubin and values were estimated by standard procedure. Histopathalogical studies of liver were also carried out.

\section{Statistical analysis:-}

Values are expressed as mean \pm SEM. The statistical analysis was done by one - way analysis of variance (ANOVA) followed by Dunnet's test. P-values $(\mathrm{P}<0.05)$ were considered as statistically siginificant.

\section{Result:-}

The hepatic enzymes SGPT (129.62 \pm 1.59$)$ (Serum Glutamate Pyruvate Transaminase), SGOT (143.65 \pm 1.01$)$ (Serum Glutamate Oxaloacetate Transaminase), ALP (88.93 \pm 0.49$) \quad$ (Alkaline Phosphatase) and bilirubin $(2.7 \pm 0.3)$ in serum were significantly $(\mathrm{P}<0.05)$ increased in paracetamol treated group when compared to control (Table.1).

The $F_{3}$ fraction of Cypraeaarabica (200 and $400 \mathrm{mg} / \mathrm{kg}$ ) significantly reversed the level of hepatic enzymes and bilirubin when compared to paracetamol treated animals, silymarin treated group were also $(\mathrm{P}<0.05)$ significantly inverted the levels of both enzymes and bilirubin levels (Table 1). The hepatoprotective effect of the $\mathrm{F}_{3}$ fraction of Cypraeaarabica was further confirmed by histopathological examination of the liver sections which revealed that the normal liver shape was disturbed in paracetamol treated rats (Plate-1c). In the liver sections of the rats treated with $\mathrm{F}_{3}$ fraction of Cypraeaarabica the normal cellular shape was regained with the absence of distortion and degradation of hepatocytes (plate1d,e). 
Table. 1: Biochemical parameters of paracetamol induced hepatoprotective activity of $\mathrm{F}_{3}$ extract of Cypraeaarabica in albino rats.

\begin{tabular}{|c|c|c|c|c|c|}
\hline Group & Dose mg/kg p.o & SGPT (Units/ml) & $\begin{array}{l}\text { SGOT } \\
\text { (Unit/ml) }\end{array}$ & $\begin{array}{l}\text { Alkaline } \\
\text { Phosphates (U/I) }\end{array}$ & $\begin{array}{l}\text { Bilirubin } \\
\text { (Mg/dl) }\end{array}$ \\
\hline 1 & Control & $\begin{array}{c}68.98 \pm \\
2.66\end{array}$ & $\begin{array}{c}80.23 \pm \\
1.08\end{array}$ & $\begin{array}{l}15.18 \pm \\
0.29\end{array}$ & $\begin{array}{l}1.13 \pm \\
0.82\end{array}$ \\
\hline 2 & $\begin{array}{l}\text { Standard Silymarin } 100 \\
\mathrm{mg} / \mathrm{kg} \text { p.o }\end{array}$ & $\begin{array}{l}69.53 \pm \\
2.94\end{array}$ & $\begin{array}{l}84.26 \pm \\
0.43\end{array}$ & $\begin{array}{c}21.45 \pm \\
0.65\end{array}$ & $\begin{array}{l}1.36 \pm \\
0.14\end{array}$ \\
\hline 3 & Paracetamol 2g/kg p.o & $\begin{array}{c}129.62 \pm \\
1.59\end{array}$ & $\begin{array}{c}143.65 \pm \\
1.01\end{array}$ & $\begin{array}{c}88.93 \pm \\
0.49\end{array}$ & $\begin{array}{l}2.7 \pm \\
0.3\end{array}$ \\
\hline 4 & Sample-I 200mg/kg p.o & $\begin{array}{c}104.73 \pm \\
1.1\end{array}$ & $\begin{array}{c}128.26 \pm \\
0.59\end{array}$ & $\begin{array}{c}80.63 \pm \\
0.66\end{array}$ & $\begin{array}{l}2.45 \pm \\
0.18\end{array}$ \\
\hline 5 & Sample I 400mg/kg p.o & $\begin{array}{c}123.84 \pm \\
1.56\end{array}$ & $\begin{array}{c}135.63 \pm \\
0.99\end{array}$ & $\begin{array}{l}71.28 \pm \\
0.45\end{array}$ & $\begin{array}{l}1.93 \pm \\
0.42\end{array}$ \\
\hline
\end{tabular}

Table-1 represented as Mean \pm SEM, Significance between Control and Extract treated groups $\mathrm{P}<0.05$.

\begin{tabular}{|l|l|l|l|l|l|l|}
\hline \multirow{5}{*}{ One Way ANOVA } & $\mathrm{F}$ & 2.66 & 2.32 & 1.45 & 1.43 & 1.61 \\
\cline { 2 - 8 } & $\mathrm{DF}$ & 3,12 & 3,12 & 3,12 & 3,12 & 3,12 \\
\cline { 2 - 7 } & $\mathrm{P}$ & $<0.05$ & $<0.05$ & $<0.05$ & $<0.05$ & $<0.05$ \\
\hline
\end{tabular}

Plate-1: Histological section showing hepatoprotective activity

(a) Control
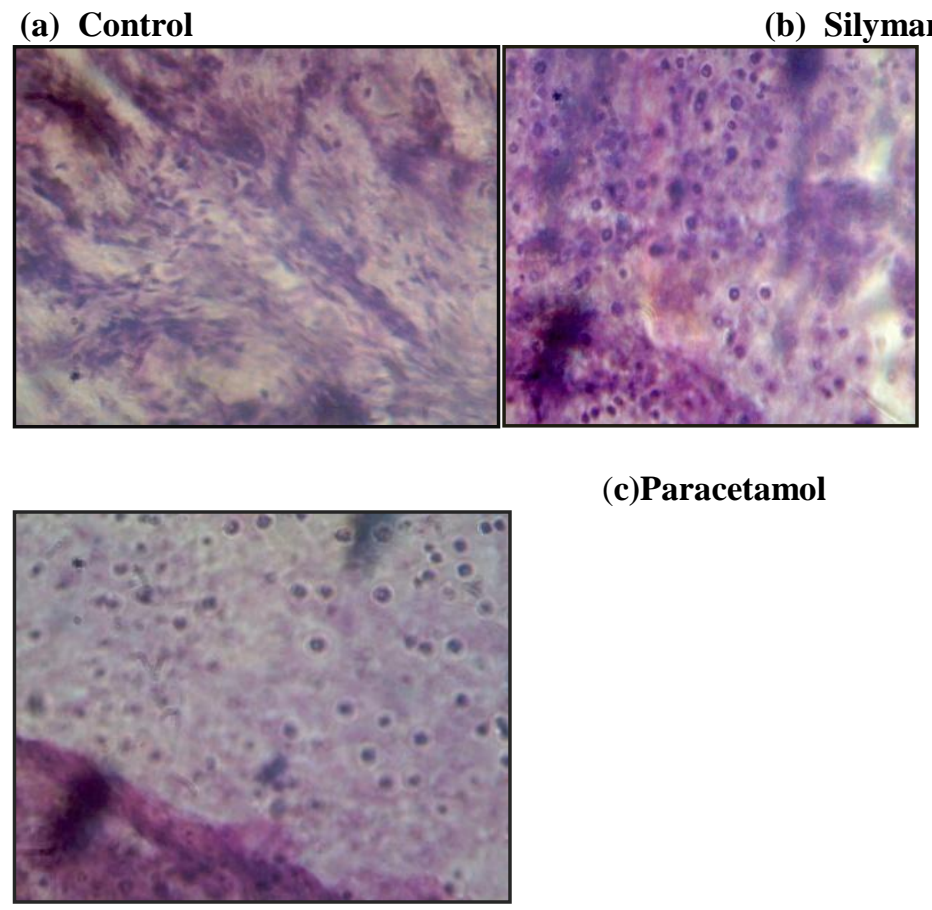

(c)Paracetamol 


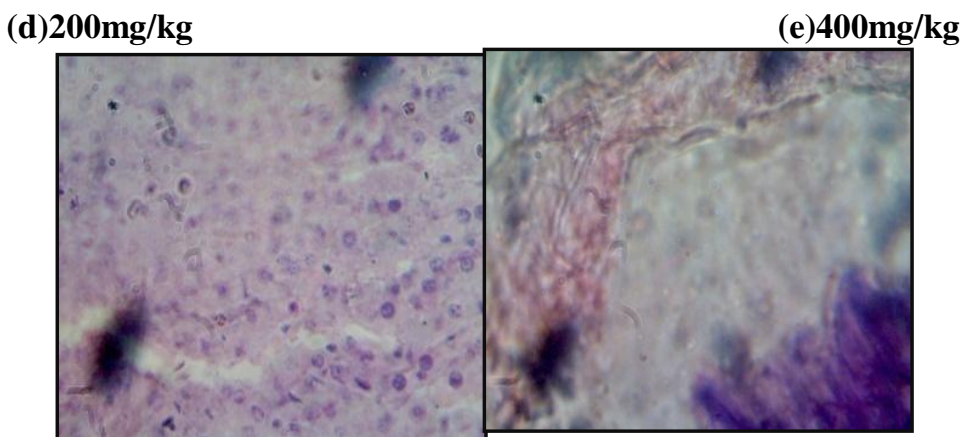

\section{Discussion:-}

Present study evaluated the hepatoprotective effects of $\mathrm{F}_{3}$ fraction of Cypraeaarabica in paracetamol induced liver necrosis. Acute administration of paracetamol produced significant elevation of SGPT, SGOT, ALP and total bilirubin levels. Treatment with $\mathrm{F}_{3}$ fraction of Cypraeaarabica decreased the elevated levels of enzymes and bilirubin level towards the respective normal values and that indicates the stabilization of plasma membrane as well as repairing of hepatic tissue damage caused by paracetamol (Plate1,c). These changes can be considered as an expression of functional improvement of hepatocytes, which may be caused by an accelerated regeneration of parenchymal cells. Silymarin is reported to have protective effect on plasma membrane of hepatocytes and possess multiple mechanisms of action against different hepatotoxic agents. The above results suggest that $F_{3}$ of Cypraeaarabica treated rats (200 and $400 \mathrm{mg} / \mathrm{kg}$ ) have gained normalcy against hepatocellular injury caused by paracetmol during the 14 day treatment period and both dose levels were found to be almost equipotent.

Similar findings were observed by (Shanmugasundram et.al., 2010) on administration of ethanol extracts of Clitoria ternate and Cassiasp indicating the improved functions of liver. The hepatoprotective activity of ethanol extract of Vitex sp. (GugulothSaravan Kumar et al., 2011) and Microcosmosexasperatus (Meenakshi et al., 2013) which limited the rapid increase of proteins and enzyme levels in albino rats. In the present study also the $\mathrm{F}_{3}$ fraction of C.arabicaregained almost normal levels of enzymes and bilirubin.

In paracetamol treated rats SGPT, SGOT, ALP and bilirubin contents in the liver increased significantly whereas the treatment with the $\mathrm{F}_{3}$ fraction of Cypraeaarabica was able to reverse the effects and bring back the level towards normal indicating the presence of bioactive compounds in the $F_{3}$ fraction. The hepatoprotective effect was also confirmed by histopathological examinations of the liver (Plate-1,c) which revealed that the normal liver shape was disturbed, distorted and degenerated by hepatotoxin in paracetamol treated rats. In the liver sections of the rats treated with $\mathrm{F}_{3}$ fraction of Cypraeaarabica, (Plate-1-d,e) the normal cellular shape was regained with the absence of distortion and degeneration of hepatocytes. The bile duct epithelium was normal with the absence of lymphocyte infiltration in the portal area as compared to Silymarin, thereby confirming the protective effect.

\section{Conclusion:-}

Chronic hepatic diseases stand as one of the foremost health troubles worldwide with liver cirrohsis and drug induced liver injury accounting ninth leading cause of death in developing countries. In the present study hepatoprotective activity of methanolic extract of Cypraeaarabica showed significant action on paracetamol induced hepato-toxicity. Further investigation is necessary to determine the pharmacologically active molecules in the methanolic extract of Cypraeaarabica that are responsible for the hepatoprotective effect. 


\section{References:-}

1. Blunt, J.W., Copp, B.R., Munro, M.H.G. Nothcote, P.T. and Prinsep, M.R.,( 2006).

2. Natural Products from Marine organism and their associated microbes. Nat. Prod. Rep., 23 23:26-78.

3. Guguloth, Saravanakumar, VivekanandanLalitha, SingaravelSengottuveluShiekhaja Sharif and ThangavelSivakumar,(2011).Hepatoprotective activity of Vivexnegundolinn bark against chemical induced toxicity in experimental rats. An Int. J. of Advan. in Pharm. Sciences .Vol.2 (5-6).

4. Meenakshi .V.K., Gomathy.S.,Senthamarai.S., Paripooranaselvi $\quad$ M., $\quad$ and Chamundeswari,(2013). Hepatoprotective activity of the ethanol extract of simple acidian, Microcosmous exasperates Heller, 1878. Euro J Zoo Res,, 20132 (4): 32-38.

5. Ravindra.S. Beedimani, Shivakumarshekar, (2015). Hepatoprotective activity of Eclipta alba against carbon tetra chloride -induced liver hepatotoxicity in abino rats. Int. J. Basic Clinpharmacol. 4 (3): 404-409.

6. Shanmugasundaram R; V KalpanaDevi ; PS Tresina; A Maruthupandian; Mohan VR.(2010). Hepatoprotective activity of ethanol extracts of Clitoriaternatea L. and Cassia angustifoliavahl leaf against $\mathrm{CCL}_{4}$ induced liver toxicity in rats. Int. Res. J. Pharm. 1 (1), 201-205.

7. Thilaga, R.D., (2005). Studies on some ecological aspects of Babylonia spirata(Linn) along the Tuticorin coast. Ph.D., Thesis, M.S. Univ. PP 244. 